\title{
Role of Silicon on Plant-Pathogen Interactions
}

\author{
Min Wang, Limin Gao, Suyue Dong, Yuming Sun, Qirong Shen and Shiwei Guo*
}

Jiangsu Provincial Key Lab for Organic Solid Waste Utilization, National Engineering Research Center for Organic-Based Fertilizers, Jiangsu Collaborative Innovation Center for Solid Organic Waste Resource Utilization, Nanjing Agricultural University, Nanjing, China

Although silicon (Si) is not recognized as an essential element for general higher plants, it has beneficial effects on the growth and production of a wide range of plant species. $\mathrm{Si}$ is known to effectively mitigate various environmental stresses and enhance plant resistance against both fungal and bacterial pathogens. In this review, the effects of Si on plant-pathogen interactions are analyzed, mainly on physical, biochemical, and molecular aspects. In most cases, the Si-induced biochemical/molecular resistance during plant-pathogen interactions were dominated as joint resistance, involving activating defense-related enzymes activates, stimulating antimicrobial compound production, regulating the complex network of signal pathways, and activating of the expression of defense-related genes. The most previous studies described an independent process, however, the whole plant resistances were rarely considered,

OPEN ACCESS

Edited by:

Rupesh Kailasrao Deshmukh, Laval University, Canada

Reviewed by:

Huixia Shou,

Zhejiang University, China

Heiner Goldbach,

University of Bonn, Germany

*Correspondence:

Shiwei Guo

sguo@njau.edu.cn

Specialty section:

This article was submitted to

Plant Nutrition,

a section of the journal

Frontiers in Plant Science

Received: 23 January 2017 Accepted: 18 April 2017

Published: 05 May 2017

Citation:

Wang M, Gao L, Dong S, Sun Y,

Shen Q and Guo S (2017) Role of Silicon on Plant-Pathogen

Interactions. Front. Plant Sci. 8:701. doi: 10.3389/fpls.2017.00701 especially the interaction of different process in higher plants. Si can act as a modulator influencing plant defense responses and interacting with key components of plant stress signaling systems leading to induced resistance. Priming of plant defense responses, alterations in phytohormone homeostasis, and networking by defense signaling components are all potential mechanisms involved in Si-triggered resistance responses. This review summarizes the roles of $\mathrm{Si}$ in plant-microbe interactions, evaluates the potential for improving plant resistance by modifying Si fertilizer inputs, and highlights future research concerning the role of Si in agriculture.

\section{Keywords: silicon, plant-pathogen interactions, physical, biochemical, molecular, defense response}

\section{INTRODUCTION}

Silicon ( $\mathrm{Si}$ ) is the second most abundant element after oxygen in the earth's crust, and comprises up to 70\% of soil mass (Epstein, 1994; Savant et al., 1997; Ma and Yamaji, 2006). Si was initially not recognized as an essential element for higher plants, although it was known to be beneficial for plant growth and production. Its accumulation among plant species differs greatly, due to differences in root Si uptake capacity (Takahashi et al., 1990). Generally, Si uptake takes place through plant roots as silicic acid $\left[\mathrm{Si}(\mathrm{OH})_{4}\right]$, an uncharged molecule (Ma and Yamaji, 2006), and passes through the plasma membrane via two Si transporters, Lsil and Lsi2, which function as influx transporters and efflux transporters, respectively (Ma et al., 2006, 2007, 2008).

Numerous studies show that $\mathrm{Si}$ accumulates in plants and exerts various beneficial effects for many plant species, especially gramineous plants such as rice and sugarcane and some cyperaceous plants (Epstein, 1994, 1999; Liang, 1999; Liang et al., 2005b). Absorbed Si is mainly deposited in 
cell walls, and is also involved with stress-related signaling systems (Fauteux et al., 2005). Si is helpful for improving the mechanical and physiological properties of plants and contributes to plants overcoming many biotic and abiotic stresses (Epstein, 1999; Richmond and Sussman, 2003; Ma, 2004; Ma and Yamaji, 2006). For example, Si enhances resistance to diseases caused by fungi, bacteria, and pests (Fauteux et al., 2005; Marschner, 2012), as well as exerting alleviative effects on various abiotic stresses including lodging, drought stress, salt stress, water logging, metal toxicity, nutrient imbalance, radiation damage, high temperature, freezing, and UV in a wide variety of plant species (Epstein, 1994, 1999; Savant et al., 1997; Ma, 2004; Ma and Yamaji, 2006; Liu et al., 2014; Coskun et al., 2016).

Many studies have focused on the role of Si on plant-microbe interactions and enhanced host resistance to a range of microbial pathogens by stimulating defense reactions (Remus-Borel et al., 2005; Cai et al., 2008; Ghareeb et al., 2011; Ye et al., 2013). However, the mechanistic basis and regulation of Si-mediated disease resistance are still poorly understood. Furthermore, the underlying mechanisms of $\mathrm{Si}$ regulated plant-microbe interactions have not been identified so far in higher plants. In this review, the effect of $\mathrm{Si}$ on plant-microbe interactions are discussed, and the physical, biochemical, and molecular regulatory mechanisms of $\mathrm{Si}$ on plant disease resistance are extensively reviewed.

Plant diseases are a major threat to agricultural production as they cause serious loss of crop yield and quality. Numerous studies have reported that $\mathrm{Si}$ is effective in controlling diseases caused by both fungal and bacterial pathogens in different plant species (Fauteux et al., 2005; Rodrigues and Datnof, 2015). A priming role of Si has been demonstrated in plantpathogen interactions and the regulation of $\mathrm{Si}$ in plant diseases is summarized in Table 1. Si plays a positive role in plant-pathogen interactions and increases plant resistance to disease caused by fungi, bacteria, viruses, and nematodes.

Silicon could alleviate plant disease through preventing pathogen penetration (1) via structural reinforcement (Epstein, 1999; Epstein, 2001; Rodrigues et al., 2015b), (2) by inhibiting pathogen colonization through stimulating systemic acquired resistance, (3) through antimicrobial compound production (Fauteux et al., 2005; Datnoff et al., 2007; Fortunato et al., 2012b; Van et al., 2013), as well as (4) through increasing plant resistance by activating multiple signaling pathways and defense-related gene expression (Fauteux et al., 2005; Chen et al., 2014; Vivancos et al., 2015). The beneficial effects of Si with regard to plant resistance to disease are attributed to $\mathrm{Si}$ accumulation in epidermal tissue, the formation of complexes with organic compounds in cell walls, the induction of phenolic compounds, phytolexin/glucanase/peroxidase production, and regulating pathogenicity or stress-related gene expression to limit pathogen invasion and colonization (Belanger et al., 2003; Brunings et al., 2009; Chain et al., 2009; Sakr, 2016). The effect of $\mathrm{Si}$ on plant-microbe interactions and related physical, biochemical, and molecular resistance mechanisms have been demonstrated in Table $\mathbf{1}$ and will be detailed discussed in the following section.

\section{SILICON-MEDIATED DISEASE RESISTANCE}

\section{Physical Mechanisms}

The beneficial effects of $\mathrm{Si}$ on plant growth are attributed to improved overall mechanical strength and an outer protective layer (Epstein, 1999, 2001; Sun et al., 2010). Successful infection requires plant pathogens to enter the host plant by penetrating physical barriers including wax, cuticles, and cell walls (Schmelzer, 2002; Nawrath, 2006; Łaźniewska et al., 2012).

Silicon-enhanced resistance is associated with the density of silicified long and short epidermal cells, the thick layer of silica under the cuticle, the double cuticular layer, the thickened Sicellulose membrane, formation of papilla, and complexes formed with organic compounds in epidermal cell walls that strengthen plants mechanically. The physical barriers inhibit pathogen penetration and make plant cells less susceptible to enzymatic degradation caused by fungal pathogen invasion (Inanaga et al., 1995; Fauteux et al., 2005; Datnoff et al., 2007; Van et al., 2013).

Silicon accumulates and, when deposited beneath the cuticle, can form a cuticle-Si double layer to prevent pathogen penetration, thereby decreasing disease incidence (Figure 1) (Ma and Yamaji, 2006, 2008). Most Si is cross-linked with hemicellulose in cell walls, which improves mechanical properties and regeneration (He et al., 2015; Guerriero et al., 2016). Si contributes not only to cell-wall rigidity and reinforcement, it also increases cell-wall elasticity during extension growth (Marschner, 2012). In primary cell walls, Si interacts with cell-wall constituents such as pectins and polyphenols, which increase cell-wall elasticity during extension growth (Emadian and Newton, 1989). In rice, Si-induced epidermal cell-wall fortification is associated with reduced severity of blast disease (Kim et al., 2002). Si application restricted hyphael entry to the first-invaded epidermal cell for wheat leaves infected with Pyricularia oryzae, while hyphae successfully invaded several neighboring leaf cells when there was no $\mathrm{Si}$ treatment (Sousa et al., 2013). A similar result was found in wheat (Bipolaris sorokiniana) pathosystem (Domiciano et al., 2013), in which Si supply delayed pathogen ingress into epidermal cells and reduced fungal colonization in foliar tissue. For rice infected with Pyricularia grisea and Rhizoctonia solani, a decrease in the number of leaf blade lesions was associated with an increased incubation period when $\mathrm{Si}$ was deposited on tissue surfaces (Rodrigues et al., 2001; Seebold et al., 2004). Moreover, the number of successful penetrative appressorial sites for $P$. oryzae was decreased in rice supplied with $\mathrm{Si}$, suggesting that the denser $\mathrm{Si}$ layer contributed to preventing or delaying pathogen penetration (Hayasaka et al., 2008).

Besides the reinforcement of cell walls by $\mathrm{Si}$, the formation of papillae has also been stimulated by $\mathrm{Si}$ during pathogen infection. Silicon accumulation was found to occur in the haustorial neck and collar area of fungus as well as in papillae, which contributed to preventing pathogen invasion (Samuels et al., 1994). Zeyen et al. (1993) demonstrated that 
TABLE 1 | Effects of silicon on plant disease and related resistance mechanisms.

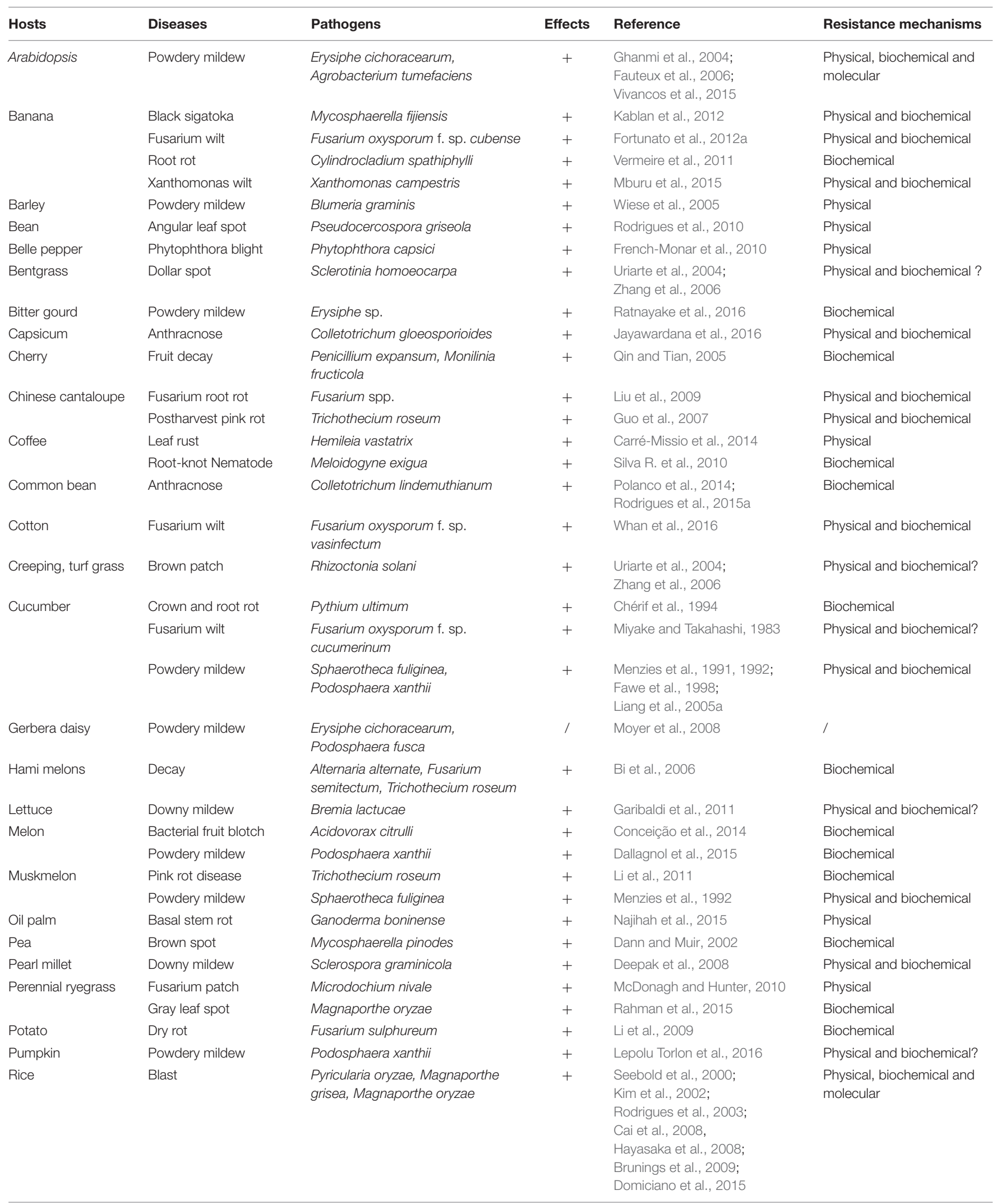


TABLE 1 | Continued

\begin{tabular}{|c|c|c|c|c|c|}
\hline Hosts & Diseases & Pathogens & Effects & Reference & Resistance mechanisms \\
\hline & Brown spot & $\begin{array}{l}\text { Bipolaris oryzae, Cochliobolus } \\
\text { miyabeanus }\end{array}$ & + & $\begin{array}{l}\text { Dallagnol et al., 2011, 2013; } \\
\text { Prabhu et al., 2012; } \\
\text { Van et al., 2015a }\end{array}$ & $\begin{array}{l}\text { Physical, biochemical and } \\
\text { molecular }\end{array}$ \\
\hline & Grain discoloration & Bipolaris oryzae & + & Prabhu et al., 2012 & Molecular \\
\hline & Leaf scald & $\begin{array}{l}\text { Monographella albescens, } \\
\text { Microdochium oryzae }\end{array}$ & + & $\begin{array}{l}\text { Tatagiba et al., 2016; } \\
\text { Araujo et al., } 2015\end{array}$ & Physical and biochemical \\
\hline & Sheath blight & Rhizoctonia solani & + & $\begin{array}{l}\text { Peters et al., 2001; } \\
\text { Schurt et al., } 2014\end{array}$ & Physical and biochemical \\
\hline Rose & Powdery mildew & Podosphaera pannosa & + & Shetty et al., 2012 & Physical \\
\hline Sorghum & Anthracnose & Colletotrichum sublineolum & + & Resende et al., 2013 & Physical and biochemical ? \\
\hline \multirow[t]{2}{*}{ Soybean } & $\begin{array}{l}\text { Phytophthora stem and } \\
\text { root rot }\end{array}$ & Phytophthora sojae & + & Guérin et al., 2014 & Molecular \\
\hline & Rust & Phakopsora pachyrhizi & + & $\begin{array}{l}\text { Cruz et al., 2014; } \\
\text { Lemes et al., } 2011\end{array}$ & Biochemical \\
\hline St. Augustinegrass & Gray leaf spot & Magnaporthe grisea & + & Brecht et al., 2007 & Physical and biochemical \\
\hline Strawberry & Powdery mildew & Sphaerotheca aphanis & + & Kanto et al., 2006 & Physical and biochemical \\
\hline Sugarcane & Brown rust & Puccinia melanocephala & + & Ramouthar et al., 2015 & Physical and biochemical ? \\
\hline Tall fescue & Brown patch & Rhizoctonia solani & - & Zhang et al., 2006 & / \\
\hline \multirow[t]{2}{*}{ Tobacco } & Viral infection & Tobacco ringspot virus & + & Zellner et al., 2011 & Molecular \\
\hline & & Tobacco mosaic virus & / & Zellner et al., 2011 & / \\
\hline \multirow[t]{3}{*}{ Tomato } & Bacterial speck & Pseudomonas syringae & + & Andrade et al., 2013 & Biochemical \\
\hline & Bacterial wilt & Ralstonia solanacearum & + & $\begin{array}{l}\text { Ghareeb et al., } 2011 ; \\
\text { Chen et al., } 2014\end{array}$ & Molecular \\
\hline & $\begin{array}{l}\text { Fusarium crown and } \\
\text { root rot }\end{array}$ & $\begin{array}{l}\text { Fusarium oxysporum f. sp } \\
\text { radicis-lycopersici }\end{array}$ & + & Huang et al., 2011 & Physical \\
\hline $\begin{array}{l}\text { Tomato, bitter } \\
\text { gourd }\end{array}$ & Root rot & Pythium aphanidermatum & + & Heine et al., 2007 & Biochemical and molecular? \\
\hline \multirow[t]{5}{*}{ Wheat } & Blast & Pyricularia grisea & + & Filha et al., 2011 & Physical and biochemical \\
\hline & Leaf blast & Pyricularia oryzae & + & Silva et al., 2015 & Biochemical \\
\hline & Leaf streak & Xanthomonas trans/ucens & + & Silva I.T. et al., 2010 & Physical and biochemical \\
\hline & Powdery mildew & Blumeria graminis & + & $\begin{array}{l}\text { Chain et al., 2009; } \\
\text { Guével et al., 2007; Moldes } \\
\text { et al., } 2016\end{array}$ & $\begin{array}{l}\text { Physical, biochemical and } \\
\text { molecular }\end{array}$ \\
\hline & Spot blotch & Bipolaris sorokiniana & + & Domiciano et al., 2010 & Physical and biochemical \\
\hline Zucchini squash & Powdery mildew & $\begin{array}{l}\text { Erysiphe cichoracearum, } \\
\text { Podosphaera xanthii }\end{array}$ & + & $\begin{array}{l}\text { Menzies et al., 1992; } \\
\text { Savvas et al., } 2009\end{array}$ & Physical and biochemical \\
\hline
\end{tabular}

Positive (+), negative (-) or no effect (/) of silicon on plant resistance to disease. ?, indicates possible defense mechanisms are involved.

barley epidermal cells could produce papillae in response to Blumeria graminis f. sp. hordei infection during Si application. A similar result has been found in the rose, in which $\mathrm{Si}$ supply increased the number of papillae in leaf cells in response to Podosphaera pannosa infection (Shetty et al., 2012). The prevalence of papillae after $\mathrm{Si}$ treatment could increase rice resistance to blast (Cai et al., 2008), wheat and barley resistance to powdery mildew (Zeyen et al., 1993; Belanger et al., 2003).

Heine et al. (2007) reported that the ability of Si to inhibit fungal spread in root apices is dependent on the uptake of $\mathrm{Si}$ into root symplasts. Further, the accumulation of $\mathrm{Si}$ on root cell walls did not represent a physical barrier to the spread of Pythium aphanidermatum in tomato or bitter gourd roots. In cucumber plants, Si foliar application could increase cucumber resistance to powdery mildew via physical barrier and osmotic effects, but Si root application can induce systemic resistance (Liang et al., 2005a). Taken together, Si, which is deposited in the wax, cuticle, and cell wall, as well as papillae, contributes in part to increased physical resistance against pathogen penetration. However, it is suggested that biochemical resistance to pathogens, as regulated by $\mathrm{Si}$, is more complex than physical resistance alone; this has been strongly contested in recent years.

\section{Biochemical Mechanisms}

Silicon-enhanced biochemical resistance is associated with (1) increasing the activity of defense-related enzymes, such as polyphenoloxidase, glucanase, peroxidase, and phenylalanine ammonia-lyase (PAL); (2) inducing antimicrobial compounds production, such as phenolic, flavonoids, phytoalexins and pathogenesis-related (PR) proteins in plants; and (3) regulating systemic signals, such as salicylic acid (SA), jasmonic acid (JA), and ethylene (ET; Fauteux et al., 2005; Datnoff et al., 2007; Fortunato et al., 2012b; Van et al., 2013). 


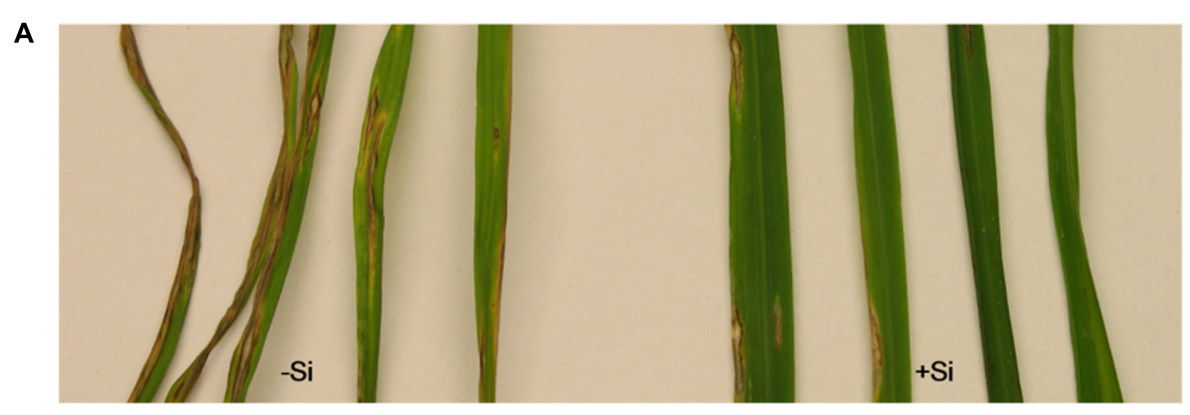

B

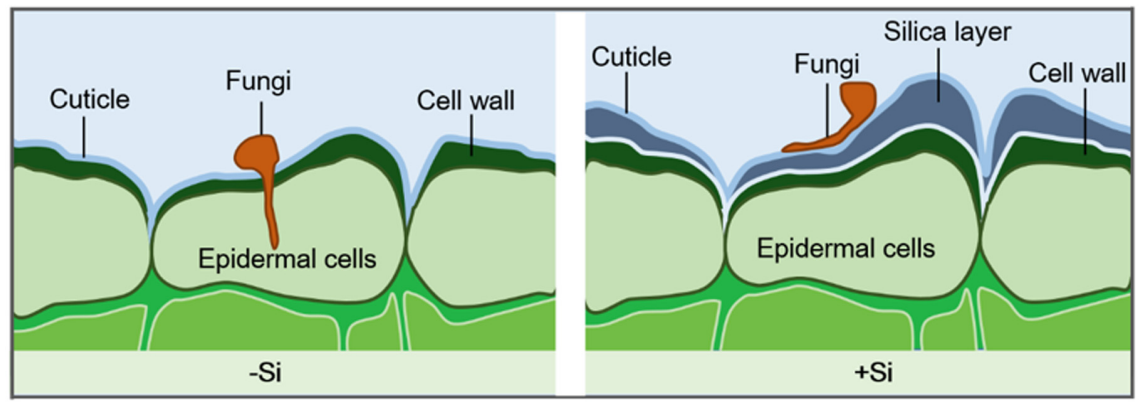

FIGURE 1 | (A) Leaf blast symptoms in rice after inoculated with Magnaporthe grisea for 10 days (Sun et al., 2010). Rice plants were continuously treated with (+Si) or without silicon (-Si). (B) Silica layer was formed in the cell wall of Si-treated plants and enhanced plant resistance to fungi infection by physical barriers.

\section{Defense-Related Enzymes and Antimicrobial Compounds}

Defense-related enzymes are closely linked with disease resistance, and $\mathrm{Si}$ has been reported to stimulate the activity of these enzymes during plant-pathogen interactions (Fauteux et al., 2005; Datnoff et al., 2007; Van et al., 2013). Several studies have reported the role of $\mathrm{Si}$ in disease resistance by activating defense-related enzyme activities such as chitinase, peroxidases, polyphenoloxidases, $\beta$-1,3-glucanase, phenylalanine ammonia-lyase, uperoxide dismutase, ascorbate peroxidase, glutathione reductase, catalase, lipoxygenase, and glucanase. PAL, involved in the synthesis of plant secondary antimicrobial substances, is essential for plant disease resistance responses (Waewthongrak et al., 2015). The higher PAL activity after Si treatment contributes to an accumulation of total soluble phenolic and lignin-thioglycolic acid derivatives in the leaves of banana and coffee plants, and this corresponds with low disease incidence (Silva R. et al., 2010; Fortunato et al., 2012b). Polyphenol oxidase (PPO), which mainly exists in cytoplasm in a free form or bound in chloroplasts, mitochondria, and other subcellular organelles, is the main enzyme of phenolic substance oxidation (Quarta et al., 2013); its activity has been positively correlated with plant disease resistance (Piperno, 2006). Furthermore, PPO was found to be involved in the synthesis of lignin and to increase the antibacterial ability of host plants (Song et al., 2016). Si application could also increase peroxidase (POD) and chitinase (CHT) activities, which play important roles in host-pathogen interactions. POD is involved in cell-wall reinforcement and the final steps of lignin biosynthesis, as well as the cross-linking of cell-wall proteins (Brisson et al., 1994), while CHT is one of the PR proteins that contribute to hydrolyze the cell walls of many phytopathogenic fungi (Pan and Ye, 1992; Shewry and Lucas, 1997).

Defense-related enzyme activities induced by Si may regulate gene expression related to enzyme synthesis; for example, the expression of genes encoding phenylalanine ammonia-lyase $(P A L a$ and $P A L b)$ and lipoxygenase $(L O X a)$ were significantly up-regulated in Si-treated perennial ryegrass plants, associated with suppression of gray leaf spot (Rahman et al., 2015). Si could elevate the activities of defense-related enzymes (e.g., peroxidase and polyphenol oxidase) via enhancing or priming JA-inducible responses to herbivory in rice (Ye et al., 2013). The beneficial effects of $\mathrm{Si}$ for suppressing pathogen infections via an increase in the activities of defenserelated enzymes have been found in the pathosystems of cucumber (Pythium spp. and Podosphaera xanthii), pea (Mycosphaerella pinodes), wheat (Pyricularia oryzae), rice (Magnaporthe oryzae, Bipolaris oryzae, Rhizoctonia solani, and Pyricularia oryzae), melon (Trichothecium roseum and Podosphaera xanthii), Chinese cantaloupe (Trichothecium roseum), bean (Colletotrichum lindemuthianum), perennial ryegrass (Magnaporthe oryzae), and soybean (Corynespora cassiicola; Table 2).

A substantial response to defense-related enzymes is the change in antimicrobial substances; generally, lower disease incidence in plants after $\mathrm{Si}$ application are associated with a higher activity of defense-related enzymes, which induce the production and accumulation of antimicrobial compounds, such as phenols, flavonoids, phytoalexins, and PR proteins in plants 
TABLE 2 | Defense-related enzymes regulated by silicon in plant-pathogen interactions.

\begin{tabular}{|c|c|c|c|c|}
\hline Hosts & Diseases & Pathogen & Defense-related enzymes & Reference \\
\hline Bean & Anthracnose & $\begin{array}{l}\text { Colletotrichum } \\
\text { lindemuthianum }\end{array}$ & $\begin{array}{l}\text { Superoxide dismutase, ascorbate peroxidase, } \\
\text { glutathione reductase }\end{array}$ & Polanco et al., 2014 \\
\hline \multirow[t]{2}{*}{ Cucumber } & Crown and root rot & Pythium spp. & Chitinase, peroxidases, polyphenoloxidases & Chérif et al., 1994 \\
\hline & Powdery mildew & Podosphaera xanthii & Peroxidases, polyphenoloxidases, chitinases & Liang et al., 2005a \\
\hline \multirow[t]{2}{*}{ Melon } & Pink rot & Trichothecium roseum & Peroxidase & Bi et al., 2006 \\
\hline & Powdery mildew & Podosphaera xanthii & Chitinases, superoxide dismutase, $\beta$-1,3-glucanase & Dallagnol et al., 2015 \\
\hline Chinese cantaloupe & Pink rot & Trichothecium roseum & Peroxidases, phenylalanine ammonia-lyase & Guo et al., 2007 \\
\hline Pea & Leaf spot & Mycosphaerella pinodes & Chitinase, $\beta$-1,3-glucanase & Dann and Muir, 2002 \\
\hline Perennial ryegrass & Gray leaf spot & Magnaporthe oryzae & Peroxidase, polyphenol oxidase & Rahman et al., 2015 \\
\hline \multirow[t]{3}{*}{ Rice } & Blast & $\begin{array}{l}\text { Magnaporthe oryzae, } \\
\text { Pyricularia oryzae }\end{array}$ & $\begin{array}{l}\text { Glucanase, peroxidase, polyphenol oxidase, } \\
\text { phenylalanine ammonia-lyase, superoxide dismutase, } \\
\text { catalase, ascorbate peroxidase, glutathione reductase, } \\
\text { lipoxygenase }\end{array}$ & $\begin{array}{l}\text { Rodrigues et al., 2003, 2004, } \\
\text { 2005; Cai et al., 2008; } \\
\text { Domiciano et al., } 2015\end{array}$ \\
\hline & Brown spot & Bipolaris oryzae & Chitinase, peroxidase & Dallagnol et al., 2011 \\
\hline & Sheath blight & Rhizoctonia solani & $\begin{array}{l}\text { Phenylalanine ammonia-lyases, peroxidases, } \\
\text { polyphenoloxidases, chitinases }\end{array}$ & Schurt et al., 2014 \\
\hline Soybean & Target spot & Corynespora cassiicola & $\begin{array}{l}\text { Chitinases, } \beta-1-3-g l u c a n a s e s, \text { phenylalanine } \\
\text { ammonia-lyases, peroxidases, polyphenol oxidases }\end{array}$ & Fortunato et al., 2015 \\
\hline Wheat & Blast & Pyricularia oryzae & Chitinases, peroxidases & Filha et al., 2011 \\
\hline
\end{tabular}

after pathogen penetration (Chérif et al., 1994; Fawe et al., 1998; Rodrigues et al., 2004; Remus-Borel et al., 2005). However, the opposite effect was found in soybeans, in which $\mathrm{Si}$ application reduced the basal antioxidant enzyme activity of leaves during Cercospora sojina infection, leading to an increase in host susceptibility to frogeye leaf spot. These findings suggest that $\mathrm{Si}$ induced resistance to plant disease was most likely due to the less than optimal conditioning of the antioxidant system (Telles Nascimento et al., 2016).

Antimicrobial compounds help higher plants to combat disease (Fauteux et al., 2005; Datnoff et al., 2007; Van et al., 2013), and Si has been documented to stimulate the accumulation of antimicrobial compounds, such as phenols, flavonoids, and phytoalexins during pathogen infection (Chérif et al., 1994; Fawe et al., 1998; Rodrigues et al., 2004; Remus-Borel et al., 2005); this may therefore contribute to the enhancement of defense-related enzyme activities. Defense-related antimicrobial phenols or lignin-associated polyphenolic compounds increased by $\mathrm{Si}$ resulted from the inducing activities of PAL and PPO following pathogen invasion (Rahman et al., 2015). Sienhanced lignin and flavonoid production is attributed to higher PAL activity induced by $\mathrm{Si}$; PAL converts $L$-phenylalanine into trans-cinnamic acid, which in turn is the precursor of lignin and flavonoids (Dixon et al., 2002; Hao et al., 2011).

Lignin and phenolic secondary metabolism play important roles in plant disease resistance. $\mathrm{Si}$ is involved in phenolic metabolism and lignin biosynthesis in plant cell walls (Marschner, 2012). It also increases lignin-carbohydrate complexes and lignin content in the epidermal cell wall of rice, and enhances plant resistance to blast disease (Inanaga et al., 1995; Cai et al., 2008). Si supply could increase the total concentration of soluble phenolic compounds in host plants and enhance plant disease resistance through delaying the growth of invading pathogens (Dallagnol et al., 2011; Fortunato et al., 2015). Flavonoids, another phenolic compound, are also induced by $\mathrm{Si}$ and enhanced rose plant resistance to Podosphaera pannosa (Shetty et al., 2012), and wheat resistance to Pyricularia oryzae (Silva et al., 2015).

Higher accumulation of phenolic and lignin or ligninthioglycolic acid derivatives, due to $\mathrm{Si}$ treatment, fortified cucumber plants against damping-off (Pythium ultimum) (Chérif et al., 1994), wheat against powdery mildew (Blumeria graminis) (Belanger et al., 2003) and blast (Pyricularia oryzae) (Filha et al., 2011), Arabidopsis against powdery mildew (Erysiphe cichoracearum) (Ghanmi et al., 2004), soybean against target spot (Corynespora cassiicola) (Fortunato et al., 2015), melon against powdery mildew (Podosphaera xanthii) (Dallagnol et al., 2015), rice against blast disease (Magnaporthe grisea) (Cai et al., 2008), brown spot (Bipolaris oryzae) (Dallagnol et al., 2011), and sheath blight (Rhizoctonia solani) (Zhang et al., 2013).

Phytoalexins is recognized to be critical in plant defense against pathogen infection. Enhanced production of phytoalexins reduces the incidence of powdery mildew caused by Podosphaera xanthii in cucumber plants (Fawe et al., 1998), as well as blast caused by M. grisea in rice (Rodrigues et al., 2004, 2005). Si supply is reported to increase accumulation of the flavonoid phytoalexins in cucumber plants during Podosphaera xanthii infection (Fawe et al., 1998). Similar results have been found in rice, in which $\mathrm{Si}$ increased resistance to blast by stimulating the production of phytoalexins, such as momilactones A and B (Rodrigues et al., 2004, 2005). With regard to perennial ryegrass (Magnaporthe oryzae) pathosystems, Si-induced enhancement of phenolic acids, including chlorogenic acid and flavonoids, and relative levels of genes encoding PAL and lipoxygenase contributed to improved resistance to gray leaf spot disease (Rahman et al., 2015). 


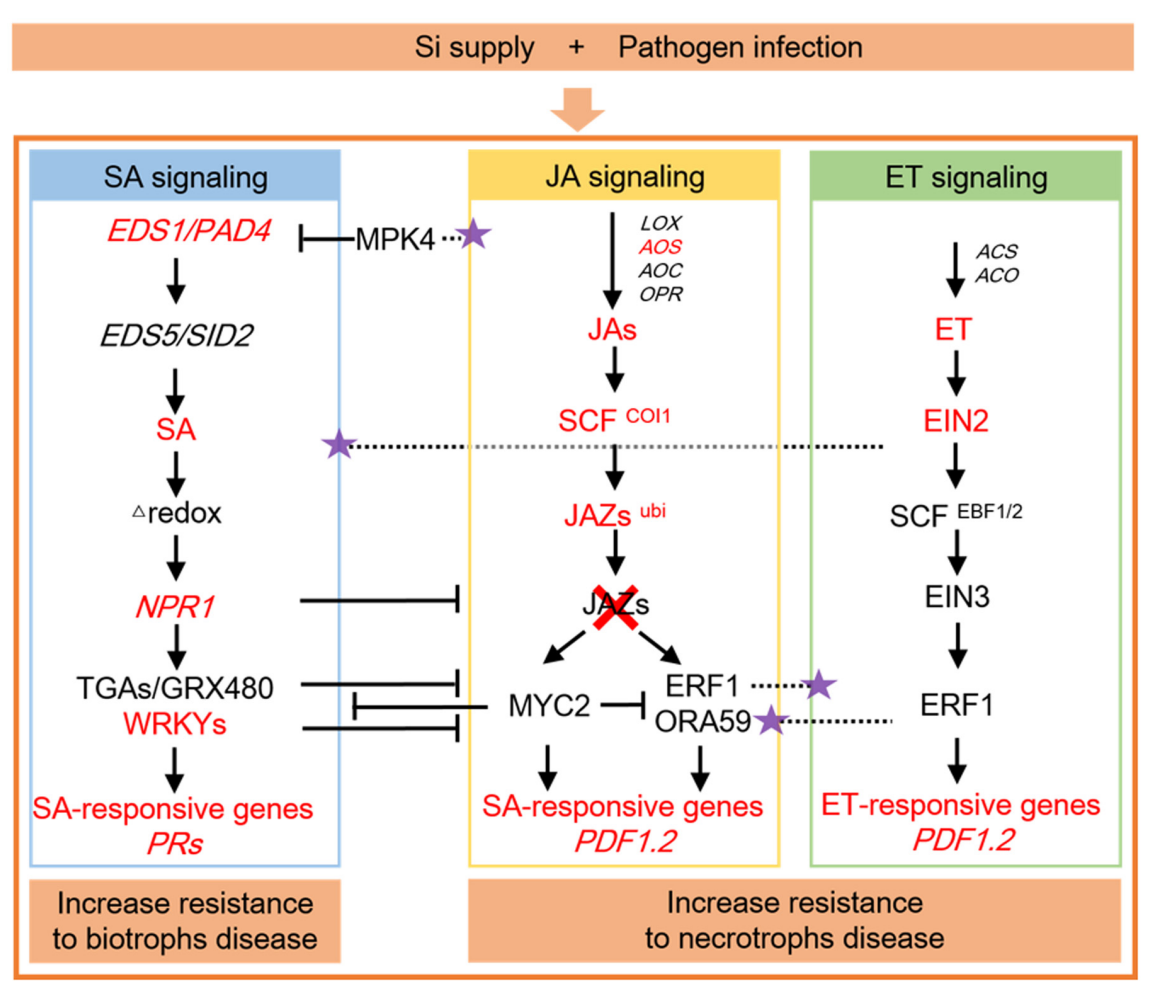

FIGURE 2 | Signaling pathways in the plant defense response regulated by silicon (Si). Crosstalk between signaling pathways in plant defense originating from the actions of salicylic acid (SA), jasmonic acid (JA), and ethylene (ET) are demonstrated, as well as their interactions in modulating the defensive response regulated by Si. The SA signaling pathway mainly involves in biotrophs disease, whereas JA and ET signaling pathways attribute to necrotrophs disease. T, negative effect; purple stars, positive effect; red, increased or up-regulated by Si supply. The networking of signaling pathways are modified from Pieterse et al. (2009).

\section{Systemic Signals}

To prevent pathogen infection, host plants have developed a complicated immune system providing several layers of constitutive and inducible defense mechanisms, which are regulated by a complex network of signal transduction pathways (Grant et al., 2013). SA, JA, and ET play key roles in plant immunity networks and regulate plant defense responses (Clarke et al., 2000; Devadas et al., 2002). SA is mainly active against biotrophic and hemibiotrophic pathogens, whereas JA and ET are predominantly involved against necrotrophic pathogens (Pieterse et al., 2012).

Several studies have suggested that Si may regulate plant stress responses by modulating phytohormone homeostasis and signaling pathways (Zhang et al., 2004; Fauteux et al., 2006; Iwai et al., 2006; De Vleesschauwer et al., 2008; Brunings et al., 2009; Chen et al., 2009; Ghareeb et al., 2011; Reynolds et al., 2016). Plant phytohormones accumulate in Si-treated plants in response to pathogen invasion, wounding, or herbivory (Fauteux et al., 2006; Ye et al., 2013; Kim et al., 2014); for example, Si-induced rice defense against insect herbivores through JA accumulation (Ye et al., 2013) and regulated wound-induced JA biosynthesis (Kim et al., 2014). In Si-treated Arabidopsis plants infected with powdery mildew pathogen (Erysiphe cichoracearum), the biosynthesis of SA, JA, and ET in leaves was stimulated, leading to increased resistance (Fauteux et al., 2006). Similarly, tomato infected with Ralstonia solanacearum showed that Si triggers activation of the JA and ET signaling pathways (Zhang et al., 2004; Chen et al., 2009; Ghareeb et al., 2011). The stimulating effects of Si on the JA and ET signaling pathways in rice challenged with Magnaporthe oryzae demonstrate that the Si-mediated signaling pathway is critical for enhancing rice resistance to blast disease (Iwai et al., 2006; De Vleesschauwer et al., 2008; Brunings et al., 2009). However, Van et al. (2015a) suggest that Si-induced rice resistance to Cochliobolus miyabeanus is regulated independently of the classic hormones SA and JA, but that it does interfere with the synthesis and/or action of fungal ET. In the defense of Arabidopsis against powdery mildew, although Si increases the expression of genes encoding enzymes involved in the SA pathway, resistant phenotypes show a significantly decreased production of SA and expression of defense genes compared with susceptible controls, implying that Si-mediated resistance involves mechanisms other than SA-dependent defense responses (Vivancos et al., 2015).

The signaling pathways in the plant defense response regulated by $\mathrm{Si}$ were demonstrated in Figure 2. The EDS1 and $P A D 4$ genes are required for SA biosynthesis, whereas the EDS5 and SID2 genes involve in regulating SA biosynthesis (Shah, 2003). In Arabidopsis, the TaLsi plant, which contained higher Si, were more resistance to Golovinomyces cichoracearum infection than control plants when treated with $\mathrm{Si}$, and corresponded with 


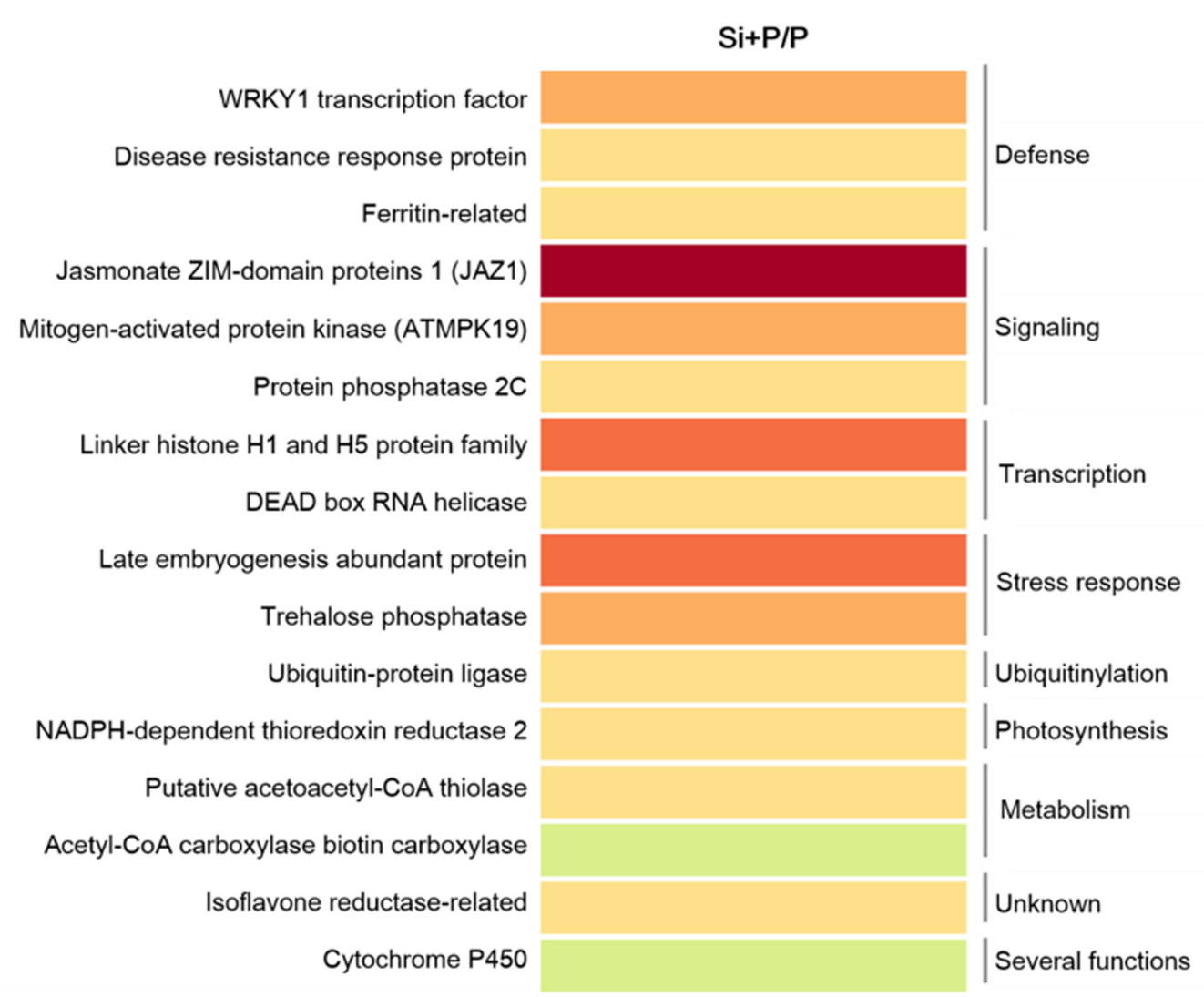

FIGURE 3 | Significantly regulated genes in response to silicon in tomato plants after infected with Ralstonia solanacearum for $72 \mathrm{~h}$ (Ghareeb et al., 2011). The heatmap represents the ratio of genes expression between plants with silicon and inoculated with $R$. solanacearum (Si $+\mathrm{P})$ and plants without silicon and inoculated with $R$. solanacearum $(\mathrm{P})$.

higher expressions of EDS1 and PAD4 genes, as well as NPR1 and three SA-induced $P R$ defense genes $P R 1, P R 2$, and $P R 5$ (Vivancos et al., 2015). Moreover, the mutants of TaLsi1 sid2 and TaLsil pad4, which crossed mutants pad4 and sid2 with the line TaLsi1, showed lower area under the disease progress curve (AUDPC) after Si supply, suggesting that Si-enhanced resistance to Golovinomyces cichoracearum infection in Arabidopsis is maintained in pad4 and sid2 mutants engineered to better absorb Si (Vivancos et al., 2015). The regulatory protein NPR1 is critical for activation of $P R$ gene expression in response to SA, and NPR1 itself is positively regulated by some SA-inducible WRKY proteins (Li et al., 2004). During tomato plant infected with $R$. solanacearum, the gene expression of transcription factor WRKY1 was upregulated in response to Si (Ghareeb et al., 2011). Si induced defense related genes and transcripts belong to the SA dependent pathway, which accompanied by an increase in the level of endogenous SA and subsequent PRs expression (Durrant and Dong, 2004; Kurabachew et al., 2013).

Silicon can induce expression of a large spectrum of inducible defense responses and amplifies the JA-mediated induced defense response by serving as a priming agent for the JA pathway
(Figure 2), for example, the enhanced induction of defenserelated enzymes and proteins, as well as enhanced induction of transcripts encoding proteins involved in JA signaling, whereas JA promotes overall leaf silicification and the maturation of phytolith-bearing silica cells by increase $\mathrm{Si}$ accumulation (Fauteux et al., 2006; Ye et al., 2013). During rice attacked by caterpillar Cnaphalocrocis medinalis (leaffolder, LF), significant decreases in Si deposition and an apparent loss of Si-induced LF resistance were observed in transgenic events that silenced the expression of either allene oxide synthase (OsAOS) or CORONATINE INSENSITIVE1 (OsCOI1), which is involved in JA biosynthesis or perception, suggesting that $\mathrm{Si}$ primes JA-mediated antiherbivore defense responses (Ye et al., 2013). Ubiquitin-protein ligase is suggested to be involved in the finetuning of JA-related response by degrading the JA-negative regulator, JAZ1 (Thines et al., 2007). Dreher and Callis (2007) demonstrated that up-regulation of ubiquitin-protein ligase by $\mathrm{Si}$ application in plants after pathogen infection may contribute to tuning the signaling of a defense response.

JERF3, TSRF1 and ACCO are ET marker genes, JERF3 is a transcription factor which is activated in response to ET and JA signaling, ACCO involved in ethylene biosynthesis, and 


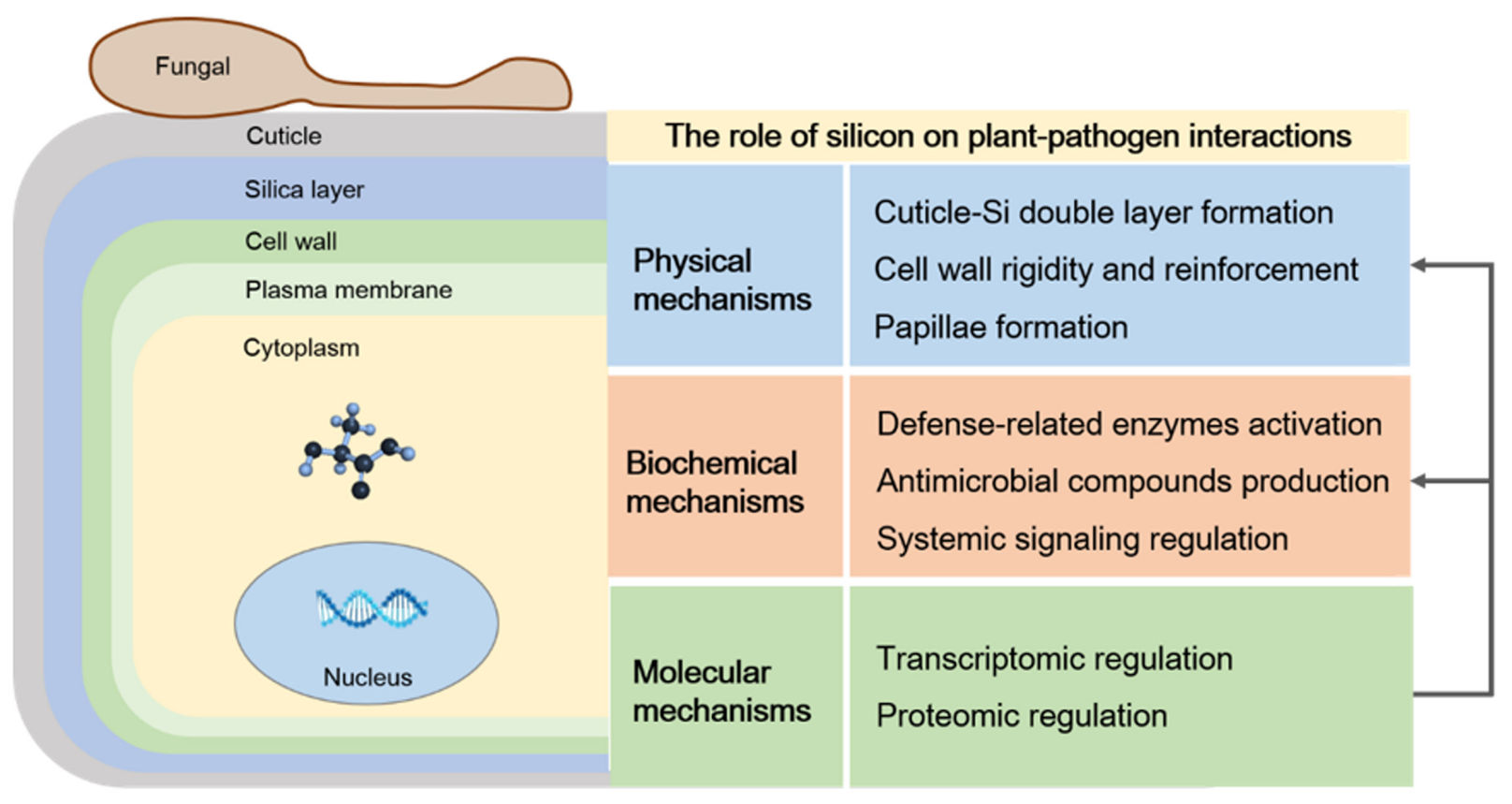

FIGURE 4 | The role of silicon (Si) on plant-pathogen interactions. Si mediated plant defense responses were classified as physical, biochemical and molecular mechanisms. Physical mechanisms involved in cell wall reinforcement and papillae deposition, biochemical mechanisms were attributed to activating defense-related enzymes, stimulating antimicrobial compounds production as well as regulating the complex network of signals pathways, and the molecular mechanisms mainly contained the regulation of genes and protein related to defense responses.

TSRF1 is an ET-responsive transcription factor (Pirrello et al., 2012). In tomato plants, the expression of JERF3, TSRF1 and ACCO genes were upregulated by $\mathrm{Si}$ when challenging with $R$. solanacearum, supporting that $\mathrm{Si}$ induced resistance were mediated via ET and JA signaling pathways (Ghareeb et al., 2011). ET and JA interact to regulate the expression of particular defense-related genes such as PDF1.2 upon pathogen perception (Pieterse et al., 2009) (Figure 2). In Arabidopsis, Si increased the PDF1.2 expression during Botrytis cinerea infection, suggesting its role as a modulator of the signaling pathways involved in the plant's response to fungal infection (Cabot et al., 2013). In riceC. miyabeanus pathosystems, ET-insensitive OsEIN2a antisense plants were more resistance to brown spot than wildtype plants, and $\mathrm{Si}$ treatment of the OsEIN $2 a$ antisense transgenics or coapplication of Si and ET signaling blocker silver thiosulfate (STS) had no additive effect on brown spot resistance, suggesting that Si specifically targets the ET signaling pathway to defense resistance (Van et al., 2015a).

Three classes of active defense mechanisms are distinguished in plant-pathogen interactions regulated by Si application: the primary response comes in cells infected by pathogens; the secondary response is induced by elicitors and restricted to cells near to the initial infection site; and thirdly, the systemic acquired response is transported hormonally to all tissues of the infected plant (Hutcheson, 1998).

\section{Molecular Mechanisms}

Silicon is involved in the metabolic processes of plant-pathogen interaction, activating defense genes of host plants via a series of physiological and biochemical reactions and signal transductions, as well as inducing the resistance response in plants to prevent plant diseases (Fauteux et al., 2005; Vivancos et al., 2015). Si may act in the primary response and modulate the activity of post-elicitation intracellular signaling systems which regulate the expression of defense genes related to structural modifications of cell walls, hypersensitivity responses, hormone synthesis, antimicrobial compound synthesis, and PR proteins (Fauteux et al., 2005).

Transcriptomic and proteomic studies have been conducted to illustrate the defense responses of $\mathrm{Si}$ in various pathosystems (Fauteux et al., 2006; Chain et al., 2009; Majeed Zargar et al., 2010; Ghareeb et al., 2011; Nwugo and Huerta, 2011). Si could induce tomato resistance to Ralstonia solanacearum via upregulating the expression of genes involved in defense and stress responses, such as WRKY1 transcription factor, disease resistance response protein, ferritin, late embryogenesis abundant protein, and trehalose phosphatase (Figure 3) (Ghareeb et al., 2011). The similar result have been found in tomato stems of rhizobacteria and silicon treated-tomato genotypes upon inoculation with $R$. solanacearum compared to the non-treated, pathogen inoculated control, in which most of the up-regulated genes are involved in signal transduction, defense, protein synthesis and metabolism, while a large proportion of down regulated genes were involved in photosynthesis, lipid metabolism (Kurabachew et al., 2013). Crosstalk between signaling pathways in plant defense regulated by $\mathrm{Si}$ and related transcription factor have been detailed discussed in the Section of "Systemic Signals" and Figure 2. During the induction of systemic acquired 
resistance in cucumber mediated with $\mathrm{Si}$, the expression of gene encoding a novel proline-rich protein (PRP1) was enhanced, which contributed to cell-wall reinforcement at the site of attempted penetration of fungi into epidermal cells (Kauss et al., 2003). During pathogen interactions in tomato plants (R. solanacearum), the expression of CHI-II, GLU, PGIP, and $P O D$, which are attributed to virulence factors released by the pathogen to inhibit host resistance and facilitate host invasion, were down-regulated by Si application (Ghareeb et al., 2011). In tomato plants inoculated with $R$. solanacearum, 26 proteins were markedly changed by Si supply, suggesting that Si-mediated disease resistance may be related to change at a protein level (Chen et al., 2014).

Silicon could negate many transcriptional changes induced by pathogen infection, for example, Arabidopsis infected with the fungus Erysiphe cichoracearum results in alteration of the expression of a set of nearly 4000 genes, and the number or expression level of up-regulated genes, which are defense-related, were not changed compared with control and Si-treated plants, whereas the magnitude of the down-regulated genes, which are involved in primary metabolism, were attenuated when treated with Si (Fauteux et al., 2006). In wheat plants infected with Blumeria graminis f. sp. tritici, about 900 genes responding to pathogen infection were altered in control leaves, while few genes were changed by the pathogen in Si-supplied plants, suggesting that $\mathrm{Si}$ almost eliminated the stress imposed by the pathogen invasion (Chain et al., 2009). Similar findings were obtained by Brunings et al. (2009), the impact of Magnaporthe oryzae inoculation on the transcriptome of rice is diminished by $\mathrm{Si}$ application. Therefore, rather than inducing resistance by transcriptional reprogramming of defense-related genes, $\mathrm{Si}$ seems to eliminate the impact of pathogen infection on the transcriptome of host plants, probably through preventing the exploitation of pathogen virulence factors (Van et al., 2015b).

\section{CONCLUSION AND PERSPECTIVES}

By combining available information on the interaction of plant-microbes mediated by $\mathrm{Si}$, the physical, biochemical, and molecular mechanisms that can be attributed to Simediated plant defense responses have been summarized in this review (Figure 4). Firstly, Si induces resistance against a wide range of diseases by acting as a physical barrier, which is based on pre-formed defense barriers before pathogen

\section{REFERENCES}

Andrade, C. C. L., Resende, R. S., Rodrigues, F., Ferraz, H. G. M., Moreira, W. R., Oliveira, J. R., et al. (2013). Silicon reduces bacterial speck development on tomato leaves. Trop. Plant Pathol. 38, 436-442. doi: 10.1590/S198256762013005000021

Araujo, L., Paschoalino, R. S., and Rodrigues, F. (2015). Microscopic aspects of silicon-mediated rice resistance to leaf scald. Phytopathology 106, 132-141. doi: 10.1094/PHYTO-04-15-0109-R

Belanger, R. R., Benhamou, N., and Menzies, J. G. (2003). Cytological evidence of an active role of silicon in wheat resistance to powdery mildew (Blumeria infection, for example, wax, cuticle, and cell-wall protection, and post-formed defense barriers after pathogen infection, for example, cell-wall reinforcement and papillae deposition at infection sites. Secondly, Si-induced biochemical resistance during plant-pathogen interactions involves activating defenserelated enzymes activates, stimulating antimicrobial compound production, and regulating the complex network of signal pathways. Finally, Si may act at a molecular level to regulate the expression of genes involved in the defense response. Understanding plant-microbe interactions regulated by $\mathrm{Si}$ will be helpful in the effective use of this mineral to increase crop yield and enhance resistance to plant diseases. Although numerous studies have elucidated the possible mechanism of Si-mediated resistance at the physical, biochemical, and molecular levels, detailed mechanisms of Si regulated plantmicrobe interactions, such as plant signaling transduction and transcriptome regulation of defense-related pathways, are needed for further study.

\section{AUTHOR CONTRIBUTIONS}

MW and SG wrote the manuscript; LG contributed in the tables; $\mathrm{SD}$ and YS contributed in the figures; QS and SG revised the manuscript.

\section{FUNDING}

This work was financially supported by the National Key R\&D Program (2016YFD0200300), the National Basic Research Program of China (2015CB150505 and 2013CB127403), the Special Fund for Agro-scientific Research in the Public Interest (20150312205), the National Natural Science Foundation of China (31401941), Jiangsu Postdoctoral Science Foundation (1402148C) and China Postdoctoral Science Foundation (2015M571768).

\section{ACKNOWLEDGMENTS}

We would like to thank Prof. Yongchao Liang for providing the result of Figure 1A. All appropriate permissions have been obtained from the copyright holders of any work that has been reproduced in this manuscript.

graminis f. sp tritici). Phytopathology 93, 402-412. doi: 10.1094/Phyto.2003.93. 4.402

Bi, Y., Tian, S. P., Guo, Y. R., Ge, Y. H., and Qin, G. Z. (2006). Sodium silicate reduces postharvest decay on Hami melons: induced resistance and fungistatic effects. Plant Dis. 90, 279-283. doi: 10.1094/pd-90-0279

Brecht, M. O., Datnoff, L. E., Kucharek, T. A., and Nagata, R. T. (2007). The influence of silicon on the components of resistance to gray leaf spot in St. Augustinegrass. J. Plant Nutr. 30, 1005-1021. doi: 10.1080/01904160701394287

Brisson, L. F., Tenhaken, R., and Lamb, C. (1994). Function of oxidative crosslinking of cell wall structural proteins in plant disease resistance. Plant Cell 6, 1703-1712. doi: 10.2307/3869902 
Brunings, A. M., Datnoff, L. E., Ma, J. F., Mitani, N., Nagamura, Y., Rathinasabapathi, B., et al. (2009). Differential gene expression of rice in response to silicon and rice blast fungus Magnaporthe oryzae. Ann. Appl. Biol. 155, 161-170. doi: 10.1111/j.1744-7348.2009.00347.x

Cabot, C., Gallego, B., Martos, S., Barceló, J., and Poschenrieder, C. (2013). Signal cross talk in Arabidopsis exposed to cadmium, silicon, and Botrytis cinerea. Planta 237, 337-349. doi: 10.1007/s00425-012-1779-7

Cai, K., Gao, D., Luo, S., Zeng, R., Yang, J., and Zhu, X. (2008). Physiological and cytological mechanisms of silicon-induced resistance in rice against blast disease. Physiol. Plant 134, 324-333. doi: 10.1111/j.1399-3054.2008. 01140.x

Carré-Missio, V., Rodrigues, F. A., Schurt, D. A., Resende, R. S., Souza, N. F. A., Rezende, D. C., et al. (2014). Effect of foliar-applied potassium silicate on coffee leaf infection by Hemileia vastatrix. Ann. Appl. Biol. 164, 396-403. doi: 10.1111/aab.12109

Chain, F., Côté-Beaulieu, C., Belzile, F., Menzies, J., and Bélanger, R. (2009). A comprehensive transcriptomic analysis of the effect of silicon on wheat plants under control and pathogen stress conditions. Mol. Plant Microbe Interact. 22, 1323-1330. doi: 10.1094/MPMI-22-11-1323

Chen, Y., Liu, M., Wang, L., Lin, W., Fan, X., and Cai, K. (2014). Proteomic characterization of silicon-mediated resistance against Ralstonia solanacearum in tomato. Plant Soil 387, 425-440. doi: 10.1007/s11104-014-2293-4

Chen, Y. Y., Lin, Y. M., Chao, T. C., Wang, J. F., Liu, A. C., Ho, F. I., et al. (2009). Virus-induced gene silencing reveals the involvement of ethylene-, salicylic acid- and mitogen-activated protein kinase-related defense pathways in the resistance of tomato to bacterial wilt. Physiol. Plant. 136, 324-335. doi: 10.1111/j.1399-3054.2009.01226.x

Chérif, M., Asselin, A., and Bélanger, R. (1994). Defense responses induced by soluble silicon in cucumber roots infected by Pythium spp. Phytopathology 84, 236-242. doi: 10.1094/Phyto-84-236

Clarke, J. D., Volko, S. M., Ledford, H., Ausubel, F. M., and Dong, X. (2000). Roles of salicylic acid, jasmonic acid, and ethylene in $c p r$-induced resistance in Arabidopsis. Plant Cell 12, 2175-2190. doi: 10.1105/tpc.12.11.2175

Conceição, C. S., Felix, K. C. S., Mariano, R. L. R., Medeiros, E. V., and Souza, E. B. (2014). Combined effect of yeast and silicon on the control of bacterial fruit blotch in melon. Sci. Hortic. 174, 164-170. doi: 10.1016/j.scienta.2014.05.027

Coskun, D., Britto, D. T., Huynh, W. Q., and Kronzucker, H. J. (2016). The role of silicon in higher plants under salinity and drought stress. Front. Plant Sci. 7:1072. doi: 10.3389/Fpls.2016.01072

Cruz, M. F. A., Rodrigues, F., Diniz, A. P. C., Alves Moreira, M., and Barros, E. G. (2014). Soybean resistance to Phakopsora pachyrhizi as affected by acibenzolarS-methyl, jasmonic acid and silicon. J. Phytopathol. 162, 133-136. doi: 10.1111/ jph. 12170

Dallagnol, L., Rodrigues, F., Pascholati, S., Fortunato, A., and Camargo, L. (2015). Comparison of root and foliar applications of potassium silicate in potentiating post-infection defences of melon against powdery mildew. Plant Pathol. 64, 1085-1093. doi: 10.1111/ppa.12346

Dallagnol, L. J., Rodrigues, F. A., Damatta, F. M., Mielli, M. V., and Pereira, S. C. (2011). Deficiency in silicon uptake affects cytological, physiological, and biochemical events in the rice-Bipolaris oryzae interaction. Phytopathology 101, 92-104. doi: 10.1094/PHYTO-04-10-0105

Dallagnol, L. J., Rodrigues, F. A., and Mielli, M. V. (2013). Silicon improves the emergence and sanity of rice seedlings obtained from seeds infected with Bipolaris oryzae. Trop. Plant Pathol. 38, 478-484. doi: 10.1590/S198256762013000600003

Dann, E. K., and Muir, S. (2002). Peas grown in media with elevated plant-available silicon levels have higher activities of chitinase and $\beta$-1, 3-glucanase, are less susceptible to a fungal leaf spot pathogen and accumulate more foliar silicon. Australas. Plant Pathol. 31, 9-13. doi: 10.1071/AP01047

Datnoff, L. E., Elmer, W. H., and Huber, D. M. (2007). Mineral Nutrition and Plant Disease. St. Paul, MN: The American Phytopathological Society.

De Vleesschauwer, D., Djavaheri, M., Bakker, P., and Hofte, M. (2008). Pseudomonas fluorescens WCS374r-induced systemic resistance in rice against Magnaporthe oryzae is based on pseudobactin-mediated priming for a salicylic acid-repressible multifaceted defense response. Plant Physiol. 148, 1996-2012. doi: 10.1104/pp.108.127878

Deepak, S., Manjunath, G., Manjula, S., Niranjan-Raj, S., Geetha, N., and Shetty, H. S. (2008). Involvement of silicon in pearl millet resistance to downy mildew disease and its interplay with cell wall proline/hydroxyproline-rich glycoproteins. Australas. Plant Pathol. 37, 498-504. doi: 10.1071/AP08047

Devadas, S. K., Enyedi, A., and Raina, R. (2002). The Arabidopsis hrl1 mutation reveals novel overlapping roles for salicylic acid, jasmonic acid and ethylene signalling in cell death and defence against pathogens. Plant J. 30, 467-480. doi: 10.1046/j.1365-313X.2002.01300.x

Dixon, R. A., Achnine, L., Kota, P., Liu, C. J., Reddy, M., and Wang, L. (2002). The phenylpropanoid pathway and plant defence-a genomics perspective. Mol. Plant Pathol. 3, 371-390. doi: 10.1046/j.1364-3703.2002.00131.x

Domiciano, G. P., Cacique, I. S., Chagas Freitas, C., Filippi, M. C., Damatta, F. M., Do Vale, F. X., et al. (2015). Alterations in gas exchange and oxidative metabolism in rice leaves infected by Pyricularia oryzae are attenuated by silicon. Phytopathology 105, 738-747. doi: 10.1094/PHYTO-10-14-0280-R

Domiciano, G. P., Rodrigues, F. A., Guerra, A. M. N., and Vale, F. X. R. (2013). Infection process of Bipolaris sorokiniana on wheat leaves is affected by silicon. Trop. Plant Pathol. 38, 258-263. doi: 10.1590/S1982-567620130050 00006

Domiciano, G. P., Rodrigues, F. A., Vale, F. X. R., Filha, M. S. X., Moreira, W. R., Andrade, C. C. L., et al. (2010). Wheat resistance to spot blotch potentiated by silicon. J. Phytopathol. 158, 334-343. doi: 10.1111/j.1439-0434.2009.01623.x

Dreher, K., and Callis, J. (2007). Ubiquitin, hormones and biotic stress in plants. Ann. Bot. 99, 787-822. doi: 10.1093/aob/mcl255

Durrant, W. E., and Dong, X. (2004). Systemic acquired resistance. Annu. Rev. Phytopathol. 42, 185-209. doi: 10.1146/annurev.phyto.42.040803.140421

Emadian, S. F., and Newton, R. J. (1989). Growth enhancement of loblolly pine (Pinus taeda L.) seedlings by silicon. J. Plant Physiol. 134, 98-103. doi: 10.1016/ S0176-1617(89)80209-3

Epstein, E. (1994). The anomaly of silicon in plant biology. Proc. Natl. Acad. Sci. U.S.A. 91, 11-17. doi: 10.1073/Pnas.91.1.11

Epstein, E. (1999). Silicon. Ann. Rev. Plant Physiol. Plant Mol. Biol. 50, 641-664. doi: 10.1146/annurev.arplant.50.1.641

Epstein, E. (2001). Silicon in Plants: Facts vs Concepts. Amsterdam: Elsevier Science.

Fauteux, F., Chain, F., Belzile, F., Menzies, J. G., and Belanger, R. R. (2006). The protective role of silicon in the Arabidopsis-powdery mildew pathosystem. Proc. Natl. Acad. Sci. U.S.A. 103, 17554-17559. doi: 10.1073/pnas.0606330103

Fauteux, F., Remus-Borel, W., Menzies, J. G., and Belanger, R. R. (2005). Silicon and plant disease resistance against pathogenic fungi. FEMS Microbiol. Lett. 249, 1-6. doi: 10.1016/j.femsle.2005.06.034

Fawe, A., Abou-Zaid, M., Menzies, J., and Bélanger, R. (1998). Silicon-mediated accumulation of flavonoid phytoalexins in cucumber. Phytopathology 88, 396-401. doi: 10.1094/PHYTO.1998.88.5.396

Filha, M. S. X., Rodrigues, F. A., Domiciano, G. P., Oliveira, H. V., Silveira, P. R., and Moreira, W. R. (2011). Wheat resistance to leaf blast mediated by silicon. Australas. Plant Pathol. 40, 28-38. doi: 10.1007/s13313-010-0010-1

Fortunato, A. A., Debona, D., Bernardeli, A. M. A., and Rodrigues, F. A. (2015). Defence-related enzymes in soybean resistance to target spot. J. Phytopathol. 163, 731-742. doi: 10.1111/jph.12370

Fortunato, A. A., Rodrigues, F., Baroni, J. C. P., Soares, G. C. B., Rodriguez, M. A. D., and Pereira, O. L. (2012a). Silicon suppresses Fusarium wilt development in banana plants. J. Phytopathol. 160, 674-679. doi: 10.1111/jph. 12005

Fortunato, A. A., Rodrigues, F., and Do Nascimento, K. J. (2012b). Physiological and biochemical aspects of the resistance of banana plants to Fusarium wilt potentiated by silicon. Phytopathology 102, 957-966. doi: 10.1094/PHYTO-0212-0037-R

French-Monar, R. D., Rodrigues, F. A., Korndörfer, G. H., and Datnoff, L. E. (2010). Silicon suppresses Phytophthora blight development on bell pepper. J. Phytopathol. 158, 554-560. doi: 10.1111/j.1439-0434.2009. 01665.x

Garibaldi, A., Gilardi, G., Cogliati, E. E., and Gullino, M. L. (2011). Silicon and increased electrical conductivity reduce downy mildew of soilless grown lettuce. Eur. J. Plant Pathol. 132, 123-132. doi: 10.1007/s10658-011-9855-6

Ghanmi, D., Mcnally, D. J., Benhamou, N., Menzies, J. G., and Bélanger, R. R. (2004). Powdery mildew of Arabidopsis thaliana: a pathosystem for exploring the role of silicon in plant-microbe interactions. Physiol. Mol. Plant Pathol. 64, 189-199. doi: 10.1016/j.pmpp.2004.07.005

Ghareeb, H., Bozsó, Z., Ott, P. G., Repenning, C., Stahl, F., and Wydra, K. (2011). Transcriptome of silicon-induced resistance against Ralstonia solanacearum in 
the silicon non-accumulator tomato implicates priming effect. Physiol. Mol. Plant Pathol. 75, 83-89. doi: 10.1016/j.pmpp.2010.11.004

Grant, M. R., Kazan, K., and Manners, J. M. (2013). Exploiting pathogens' tricks of the trade for engineering of plant disease resistance: challenges and opportunities. Microb. Biotechnol. 6, 212-222. doi: 10.1111/1751-7915.12017

Guérin, V., Lebreton, A., Cogliati, E. E., Hartley, S. E., Belzile, F., Menzies, J. G., et al. (2014). A zoospore inoculation method with Phytophthora sojae to assess the prophylactic role of silicon on soybean cultivars. Plant Dis. 98, 1632-1638. doi: 10.1094/pdis-01-14-0102-re

Guerriero, G., Hausman, J. F., and Legay, S. (2016). Silicon and the plant extracellular matrix. Front. Plant Sci. 7:463. doi: 10.3389/Fpls.2016.00463

Guével, M. H., Menzies, J. G., and Bélanger, R. R. (2007). Effect of root and foliar applications of soluble silicon on powdery mildew control and growth of wheat plants. Eur. J. Plant Pathol. 119, 429-436. doi: 10.1007/s10658-007-9181-1

Guo, Y., Liu, L., Zhao, J., and Bi, Y. (2007). Use of silicon oxide and sodium silicate for controlling Trichothecium roseum postharvest rot in Chinese cantaloupe (Cucumis melo L.). Int. J. Food Sci. Techol. 42, 1012-1018. doi: 10.1111/j.13652621.2006.01464.x

Hao, Z., Wang, L., He, Y., Liang, J., and Tao, R. (2011). Expression of defense genes and activities of antioxidant enzymes in rice resistance to rice stripe virus and small brown planthopper. Plant Physiol. Biochem. 49, 744-751. doi: 10.1016/j.plaphy.2011.01.014

Hayasaka, T., Fujii, H., and Ishiguro, K. (2008). The role of silicon in preventing appressorial penetration by the rice blast fungus. Phytopathology 98, 1038-1044. doi: 10.1094/PHYTO-98-9-1038

He, C. W., Ma, J., and Wang, L. J. (2015). A hemicellulose-bound form of silicon with potential to improve the mechanical properties and regeneration of the cell wall of rice. New Phytol. 206, 1051-1062. doi: 10.1111/nph.13282

Heine, G., Tikum, G., and Horst, W. J. (2007). The effect of silicon on the infection by and spread of Pythium aphanidermatum in single roots of tomato and bitter gourd. J. Exp. Bot. 58, 569-577. doi: 10.1093/jxb/erl232

Huang, C.-H., Roberts, P. D., and Datnoff, L. E. (2011). Silicon suppresses Fusarium crown and root rot of tomato. J. Phytopathol. 159, 546-554. doi: $10.1111 / j .1439-0434.2011 .01803 . x$

Hutcheson, S. W. (1998). Current concepts of active defense in plants. Annu. Rev. Phytopathol. 36, 59-90. doi: 10.1146/annurev.phyto.36.1.59

Inanaga, S., Okasaka, A., and Tanaka, S. (1995). Does silicon exist in association with organic compounds in rice plant? Soil Sci. Plant Nutr. 41, 111-117. doi: 10.1080/00380768.1995.10419564

Iwai, T., Miyasaka, A., Seo, S., and Ohashi, Y. (2006). Contribution of ethylene biosynthesis for resistance to blast fungus infection in young rice plants. Plant Physiol. 142, 1202. doi: 10.1104/pp.106.085258

Jayawardana, H. A. R. K., Weerahewa, H. L. D., and Saparamadu, M. D. J. S. (2016). The mechanisms underlying the Anthracnose disease reduction by rice hull as a silicon source in capsicum (Capsicum annuum L.) grown in simplified hydroponics. Procedia Food Sci. 6, 147-150. doi: 10.1016/j.profoo.2016.02.035

Kablan, L., Lagauche, A., Delvaux, B., and Legrève, A. (2012). Silicon reduces black sigatoka development in banana. Plant Dis. 96, 273-278. doi: 10.1094/pdis-0411-0274

Kanto, T., Miyoshi, A., Ogawa, T., Maekawa, K., and Aino, M. (2006). Suppressive effect of liquid potassium silicate on powdery mildew of strawberry in soil. J.Gen. Plant Pathol. 72, 137-142. doi: 10.1007/s10327-005-0270-8

Kauss, H., Kai, S., Franke, R., Gilbert, S., Dietrich, R. A., and Kröger, N. (2003). Silica deposition by a strongly cationic proline-rich protein from systemically resistant cucumber plants. Plant J. 33, 87-95. doi: 10.1046/j.1365-313X.2003. 01606.x

Kim, S. G., Kim, K. W., Park, E. W., and Choi, D. (2002). Silicon-induced cell wall fortification of rice leaves: a possible cellular mechanism of enhanced host resistance to blast. Phytopathology 92, 1095-1103. doi: 10.1094/PHYTO.2002. 92.10.1095

Kim, Y. H., Khan, A. L., Kim, D. H., Lee, S. Y., Kim, K. M., Waqas, M., et al. (2014). Silicon mitigates heavy metal stress by regulating P-type heavy metal ATPases, Oryza sativa low silicon genes, and endogenous phytohormones. BMC Plant Biol. 14:13. doi: 10.1186/1471-2229-14-13

Kurabachew, H., Stahl, F., and Wydra, K. (2013). Global gene expression of rhizobacteria-silicon mediated induced systemic resistance in tomato (Solanum lycopersicum) against Ralstonia solanacearum. Physiol. Mol. Plant Pathol. 84, 44-52. doi: 10.1016/j.pmpp.2013.06.004
Łaźniewska, J., Macioszek, V. K., and Kononowicz, A. K. (2012). Plant-fungus interface: the role of surface structures in plant resistance and susceptibility to pathogenic fungi. Physiol. Mol. Plant Pathol. 78, 24-30. doi: 10.1016/j.pmpp. 2012.01.004

Lemes, E. M., Mackowiak, C. L., Blount, A., Marois, J. J., Wright, D. L., Coelho, L., et al. (2011). Effects of silicon applications on soybean rust development under greenhouse and field conditions. Plant Dis. 95, 317-324. doi: 10.1094/pdis-0710-0500

Lepolu Torlon, J., Heckman, J., Simon, J., and Wyenandt, C. (2016). Silicon soil amendments for suppressing powdery mildew on pumpkin. Sustainability 8:293. doi: $10.3390 /$ su8040293

Li, J., Brader, G., and Palva, E. T. (2004). The WRKY70 transcription factor: a node of convergence for jasmonate-mediated and salicylate-mediated signals in plant defense. Plant Cell 16, 319-331. doi: 10.1105/tpc.016980

Li, W., Bi, Y., Ge, Y., Li, Y., Wang, J., and Wang, Y. (2011). Effects of postharvest sodium silicate treatment on pink rot disease and oxidative stress-antioxidative system in muskmelon fruit. Eur. Food Res. Technol. 234, 137-145. doi: 10.1007/ s00217-011-1611-9

Li, Y. C., Bi, Y., Ge, Y. H., Sun, X. J., and Wang, Y. (2009). Antifungal activity of sodium silicate on Fusarium sulphureum and its effect on dry rot of potato tubers. J. Food Sci. 74, 213-218. doi: 10.1111/j.1750-3841.2009.01154.x

Liang, Y. C. (1999). Effects of silicon on enzyme activity and sodium, potassium and calcium concentration in barley under salt stress. Plant Soil 209, 217-224. doi: 10.1023/A:1004526604913

Liang, Y. C., Sun, W., Si, J., and Römheld, V. (2005a). Effects of foliar-and rootapplied silicon on the enhancement of induced resistance to powdery mildew in Cucumis sativus. Plant Pathol. 54, 678-685. doi: 10.1111/j.1365-3059.2005. 01246.x

Liang, Y. C., Wong, J. W. C., and Wei, L. (2005b). Silicon-mediated enhancement of cadmium tolerance in maize (Zea mays L.) grown in cadmium contaminated soil. Chemosphere 58, 475-483. doi: 10.1016/j.chemosphere.2004. 09.034

Liu, L., Guo, Y., Bi, Y., Li, M., Zhao, J., and Zhao, H. (2009). Inhabited mechanisms of silicon compounds against Fusarium rot (Fusarium spp.) of postharvest Chinese cantaloupe. J. Food Process. Preserv. 33, 187-202. doi: 10.1111/j.17454549.2008.00292.x

Liu, P., Yin, L. N., Deng, X. P., Wang, S. W., Tanaka, K., and Zhang, S. Q. (2014). Aquaporin-mediated increase in root hydraulic conductance is involved in silicon-induced improved root water uptake under osmotic stress in Sorghum bicolor L. J. Exp. Bot. 65, 4747-4756. doi: 10.1093/jxb/eru220

Ma, J. F. (2004). Role of silicon in enhancing the resistance of plants to biotic and abiotic stresses. Soil Sci. Plant Nutr. 50, 11-18. doi: 10.1080/00380768.2004. 10408447

Ma, J. F., Tamai, K., Yamaji, N., Mitani, N., Konishi, S., Katsuhara, M., et al. (2006). A silicon transporter in rice. Nature 440, 688-691. doi: 10.1038/nature 04590

Ma, J. F., and Yamaji, N. (2006). Silicon uptake and accumulation in higher plants. Trends Plant Sci. 11, 392-397. doi: 10.1016/j.tplants.2006.06.007

Ma, J. F., and Yamaji, N. (2008). Functions and transport of silicon in plants. Cell. Mol. Life Sci. 65, 3049-3057. doi: 10.1007/s00018-008-7580-x

Ma, J. F., Yamaji, N., Mitani, N., Tamai, K., Konishi, S., Fujiwara, T., et al. (2007). An efflux transporter of silicon in rice. Nature 448, 209-212. doi: 10.1038/ nature 05964

Ma, J. F., Yamaji, N., Mitani, N., Xu, X. Y., Su, Y. H., Mcgrath, S. P., et al. (2008). Transporters of arsenite in rice and their role in arsenic accumulation in rice grain. Proc. Natl. Acad. Sci. U.S.A. 105, 9931-9935. doi: 10.1073/pnas. 0802361105

Majeed Zargar, S., Nazir, M., Kumar Agrawal, G., Kim, D. W., and Rakwal, R. (2010). Silicon in plant tolerance against environmental stressors: towards crop improvement using omics approaches. Curr. Proteomics 7, 135-143. doi: 10. 2174/157016410791330507

Marschner, P. (2012). Marschner's Mineral Nutrition of Higher Plants. London: Academic Press.

Mburu, K., Oduor, R., Mgutu, A., and Tripathi, L. (2015). Silicon application enhances resistance to xanthomonas wilt disease in banana. Plant Pathol. 65, 807-818. doi: 10.1111/ppa. 12468

McDonagh, D., and Hunter, A. (2010). Effect of silicon application on Lolium perenne development and Fusarium control. Paper presented at the XXVIII 
International Horticultural Congress on Science and Horticulture for People (IHC2010), Lisbon, 195-201.

Menzies, J., Bowen, P., Ehret, D., and Glass, A. D. (1992). Foliar applications of potassium silicate reduce severity of powdery mildew on cucumber, muskmelon, and zucchini squash. J. Am. Soc. Hortic. Sci. 117, 902-905.

Menzies, J., Ehret, D., Glass, A., and Samuels, A. (1991). The influence of silicon on cytological interactions between Sphaerotheca fuliginea and Cucumis sativus. Physiol. Mol. Plant Pathol. 39, 403-414. doi: 10.1016/0885-5765(91)90007-5

Miyake, Y., and Takahashi, E. (1983). Effect of silicon on the growth of solutioncultured cucumber plant. Soil Sci. Plant Nutr. 29, 71-83. doi: 10.1080/00380768. 1983.10432407

Moldes, C. A., De Lima Filho, O. F., Merini, L. J., Tsai, S. M., and Camiña, J. M. (2016). Occurrence of powdery mildew disease in wheat fertilized with increasing silicon doses: a chemometric analysis of antioxidant response. Acta Physiol. Plant. 38, 206. doi: 10.1007/s11738-016-2217-4

Moyer, C., Peres, N. A., Datnoff, L. E., Simonne, E. H., and Deng, Z. (2008). Evaluation of silicon for managing powdery mildew on gerbera daisy. J. Plant Nutr. 31, 2131-2144. doi: 10.1080/01904160802459641

Najihah, N. I., Hanafi, M. M., Idris, A. S., and Hakim, M. A. (2015). Silicon treatment in oil palms confers resistance to basal stem rot disease caused by Ganoderma boninense. Crop Prot. 67, 151-159. doi: 10.1016/j.cropro.2014. 10.004

Nawrath, C. (2006). Unraveling the complex network of cuticular structure and function. Curr. Opin. Plant Biol. 9, 281-287. doi: 10.1016/j.pbi.2006.03.001

Nwugo, C. C., and Huerta, A. J. (2011). The effect of silicon on the leaf proteome of rice (Oryza sativa L.) plants under cadmium-stress. J. Proteome Res. 10, 518-528. doi: $10.1021 / \mathrm{pr} 100716 \mathrm{~h}$

Pan, S., and Ye, X. (1992). Induction of chitinases in tobacco plants systemically protected against blue mold by Peronospora tabacina or tobacco mosaic virus. Phytopathology 82, 119-123. doi: 10.1094/Phyto-82-119

Peters, F. R., Datnoff, L., Korndörfer, G., Seebold, K., and Rush, M. (2001). Effect of silicon and host resistance on sheath blight development in rice. Plant Dis. 85, 827-832. doi: 10.1094/PDIS.2001.85.8.827

Pieterse, C. M., Leon-Reyes, A., Van Der Ent, S., and Van Wees, S. C. (2009). Networking by small-molecule hormones in plant immunity. Nat. Chem. Biol. 5, 308-316. doi: 10.1038/nchembio.164

Pieterse, C. M., Van, D. D. D., Zamioudis, C., Leonreyes, A., and Van Wees, S. C. (2012). Hormonal modulation of plant immunity. Cell Dev. Biol. 28, 489-521. doi: 10.1146/annurev-cellbio-092910-154055

Piperno, D. R. (ed.) (2006). "The production, deposition, and dissolution of phytoliths," in Phytoliths: A Comprehensive Guide for Archaeologists and Paleoecologists, (Lanham, MD: AltaMira Press).

Pirrello, J., Prasad, B. N., Zhang, W., Chen, K., Mila, I., Zouine, M., et al. (2012). Functional analysis and binding affinity of tomato ethylene response factors provide insight on the molecular bases of plant differential responses to ethylene. BMC Plant Biol. 12:190. doi: 10.1186/1471-2229-12-190

Polanco, L. R., Rodrigues, F. A., Nascimento, K. J., Cruz, M. F., Curvelo, C. R., Damatta, F. M., et al. (2014). Photosynthetic gas exchange and antioxidative system in common bean plants infected by Colletotrichum lindemuthianum and supplied with silicon. Trop. Plant Pathol. 39, 35-42. doi: 10.1590/S198256762014000100005

Prabhu, A. S., Barbosa Filho, M. P., Datnoff, L. E., Snyder, G. H., Berni, R. F., Rodrigues, F. A., et al. (2012). Silicon reduces brown spot severity and grain discoloration on several rice genotypes. Trop. Plant Pathol. 37, 409-414. doi: 10.1590/S1982-56762012000600005

Qin, G. Z., and Tian, S. P. (2005). Enhancement of biocontrol activity of Cryptococcus laurentii by silicon and the possible mechanisms involved. Phytopathology 95, 69-75. doi: 10.1094/PHYTO-95-0069

Quarta, A., Mita, G., Durante, M., Arlorio, M., and De, P. A. (2013). Isolation of a polyphenol oxidase (PPO) cDNA from artichoke and expression analysis in wounded artichoke heads. Plant Physiol. Biochem. 68, 52-60. doi: 10.1016/j. plaphy.2013.03.020

Rahman, A., Wallis, C. M., and Uddin, W. (2015). Silicon-induced systemic defense responses in perennial ryegrass against infection by Magnaporthe oryzae. Phytopathology 105, 748-757. doi: 10.1094/PHYTO-12-14-0378-R

Ramouthar, P. V., Caldwell, P. M., and Mcfarlane, S. A. (2015). Effect of silicon on the severity of brown rust of sugarcane in South Africa. Eur. J. Plant Pathol. 145, 53-60. doi: 10.1007/s10658-015-0812-7
Ratnayake, R. M. R. N. K., Daundasekera, W. A. M., Ariyarathne, H. M., and Ganehenege, M. Y. U. (2016). Some biochemical defense responses enhanced by soluble silicon in bitter gourd-powdery mildew pathosystem. Australas. Plant Pathol. 45, 425-433. doi: 10.1007/s13313-016-0429-0

Remus-Borel, W., Menzies, J. G., and Belanger, R. R. (2005). Silicon induces antifungal compounds in powdery mildew-infected wheat. Physiol. Mol. Plant Pathol. 66, 108-115. doi: 10.1016/j.pmpp.2005.05.006

Resende, R. S., Rodrigues, F., Costa, R. V., and Silva, D. D. (2013). Silicon and fungicide effects on anthracnose in moderately resistant and susceptible sorghum lines. J. Phytopathol. 161, 11-17. doi: 10.1111/jph.12020

Reynolds, O. L., Padula, M. P., Zeng, R. S., and Gurr, G. M. (2016). Silicon: potential to promote direct and indirect effects on plant defense against arthropod pests in agriculture. Front. Plant Sci. 7:744. doi: 10.3389/fpls.2016.00744

Richmond, K. E., and Sussman, M. (2003). Got silicon? The non-essential beneficial plant nutrient. Curr. Opin. Plant Biol. 6, 268-272. doi: 10.1016/S1369-5266(03) 00041-4

Rodrigues, F., Benhamou, N., Datnoff, L. E., Jones, J. B., and Bélanger, R. R. (2003). Ultrastructural and cytochemical aspects of silicon-mediated rice blast resistance. Phytopathology 93, 535-546. doi: 10.1094/PHYTO.2003.93. 5.535

Rodrigues, F., Duarte, H. S. S., Rezende, D. C., Filho, J. A. W., Korndörfer, G. H., and Zambolim, L. (2010). Foliar spray of potassium silicate on the control of angular leaf spot on beans. J. Plant Nutr. 33, 2082-2093. doi: 10.1080/01904167. 2010.519082

Rodrigues, F. A., and Datnof, L. E. (2015). Silicon and Plant Diseases. Berlin: Springer. doi: 10.1007/978-3-319-22930-0

Rodrigues, F. A., Datnoff, L. E., Korndorfer, G. H., Seebold, K. W., and Rush, M. C. (2001). Effect of silicon and host resistance on sheath blight development in rice. Plant Dis. 85, 827-832. doi: 10.1094/PDIS.2001.85.8.827

Rodrigues, F. A., Jurick, W. M., Datnoff, L. E., Jones, J. B., and Rollins, J. A. (2005). Silicon influences cytological and molecular events in compatible and incompatible rice-Magnaporthe grisea interactions. Physiol. Mol. Plant Pathol. 66, 144-159. doi: 10.1016/j.pmpp.2005.06.002

Rodrigues, F. A., Mcnally, D. J., Datnoff, L. E., Jones, J. B., Labbé, C., Benhamou, N., et al. (2004). Silicon enhances the accumulation of diterpenoid phytoalexins in rice: a potential mechanism for blast resistance. Phytopathology 94, 177-183. doi: 10.1094/PHYTO.2004.94.2.177

Rodrigues, F. A., Polanco, L. R., Duarte, H. S. S., Resende, R. S., and Do Vale, F. X. R. (2015a). Photosynthetic gas exchange in common bean submitted to foliar sprays of potassium silicate, sodium molybdate and fungicide and infected with Colletotrichum lindemuthianum. J. Phytopathol. 163, 554-559. doi: 10.1111/jph. 12353

Rodrigues, F. A., Resende, R. S., Dallagnol, L. J., and Datnoff, L. E. (2015b). Silicon Potentiates Host Defense Mechanisms against Infection by Plant Pathogens. Cham: Springer International Publishing. doi: 10.1007/978-3-319-22930-0_5

Sakr, N. (2016). The role of silicon (Si) in increasing plant resistance against fungal diseases. Hell. Plant Protect. J. 9, 1-15. doi: 10.1515/hppj-2016-0001

Samuels, A. L., Adm, G., Menzies, J. G., and Ehret, D. L. (1994). Silicon in cell walls and papillae of Cucumis sativus during infection by Sphaerotheca fuliginea. Physiol. Mol. Plant Pathol. 44, 237-242. doi: 10.1016/S0885-5765(05)80027-X

Savant, N. K., Snyder, G. H., and Datnoff, L. E. (1997). Silicon management and sustainable rice production. Adv. Agron. 58, 151-199. doi: 10.1016/S00652113(08)60255-2

Savvas, D., Giotis, D., Chatzieustratiou, E., Bakea, M., and Patakioutas, G. (2009). Silicon supply in soilless cultivations of zucchini alleviates stress induced by salinity and powdery mildew infections. Environ. Exp. Bot. 65, 11-17. doi: 10.1016/j.envexpbot.2008.07.004

Schmelzer, E. (2002). Cell polarization, a crucial process in fungal defence. Trends Plant Sci. 7, 411-415. doi: 10.1016/S1360-1385(02)02307-5

Schurt, D. A., Cruz, M. F., Nascimento, K. J., Filippi, M. C., and Rodrigues, F. A. (2014). Silicon potentiates the activities of defense enzymes in the leaf sheaths of rice plants infected by Rhizoctonia solani. Trop. Plant Pathol. 39, 457-463. doi: 10.1590/S1982-56762014000600007

Seebold, K. W., Datnoff, L., Correa-Victoria, F. J., Kucharek, T. A., and Snyder, G. H. (2000). Effect of silicon rate and host resistance on blast, scald, and yield of upland rice. Plant Dis. 84, 871-876. doi: 10.1094/PDIS.2000.84.8.871

Seebold, K. W., Datnoff, L. E., Correa-Victoria, F. J., Kucharek, T. A., and Snyder, G. H. (2004). Effects of silicon and fungicides on the control of leaf and 
neck blast in upland rice. Plant Dis. 88, 253-258. doi: 10.1094/Pdis.2004.88. 3.253

Shah, J. (2003). The salicylic acid loop in plant defense. Curr. Opin. Plant Biol. 6, 365-371. doi: 10.1016/S1369-5266(03)00058-X

Shetty, R., Jensen, B., Shetty, N. P., Hansen, M., Hansen, C. W., Starkey, K. R., et al. (2012). Silicon induced resistance against powdery mildew of roses caused by Podosphaera pannosa. Plant Pathol. 61, 120-131. doi: 10.1111/j.1365-3059. 2011.02493.x

Shewry, P. R., and Lucas, J. A. (1997). Plant proteins that confer resistance to pests and pathogens. Adv. Bot. Res. 26, 135-192. doi: 10.1016/S0065-2296(08) 60120-2

Silva, I. T., Rodrigues, F. A., Oliveira, J. R., Pereira, S. C., Andrade, C. C. L., Silveira, P. R., et al. (2010). Wheat resistance to bacterial leaf streak mediated by silicon. J. Phytopathol. 158, 253-262. doi: 10.1111/j.1439-0434.2009. 01610.x

Silva, R., Oliveira, R., Nascimento, K., and Rodrigues, F. (2010). Biochemical responses of coffee resistance against Meloidogyne exigua mediated by silicon. Plant Pathol. 59, 586-593. doi: 10.1111/j.1365-3059.2009.02228.x

Silva, W. L. D., Cruz, M. F. A., Fortunato, A. A., and Rodrigues, F. (2015). Histochemical aspects of wheat resistance to leaf blast mediated by silicon. Sci. Agric. 72, 322-327. doi: 10.1590/0103-9016-2014-0221

Song, A., Xue, G., Cui, P., Fan, F., Liu, H., Chang, Y., et al. (2016). The role of silicon in enhancing resistance to bacterial blight of hydroponic- and soil-cultured rice. Sci. Rep. 6:24640. doi: 10.1038/srep24640

Sousa, R. S., Rodrigues, F. A., Schurt, D. A., Souza, N. F. A., and Cruz, M. F. A. (2013). Cytological aspects of the infection process of Pyricularia oryzae on leaves of wheat plants supplied with silicon. Trop. Plant Pathol. 38, 472-477. doi: 10.1590/S1982-56762013000600002

Sun, W., Zhang, J., Fan, Q., Xue, G., Li, Z., and Liang, Y. (2010). Silicon-enhanced resistance to rice blast is attributed to silicon-mediated defence resistance and its role as physical barrier. Eur. J. Plant Pathol. 128, 39-49. doi: 10.1007/s10658010-9625-x

Takahashi, E., Ma, J. F., and Miyake, Y. (1990). The possibility of silicon as an essential element for higher plants. Comment. Agric. Food Chem. 2, 99-102. doi: 10.1016/j.bbagen.2013.11.021

Tatagiba, S. D., Damatta, F. M., and Rodrigues, F. A. (2016). Silicon partially preserves the photosynthetic performance of rice plants infected by Monographella albescens. Ann. Appl. Biol. 168, 111-121. doi: 10.1111/aab. 12246

Telles Nascimento, K. J., Debona, D., Silva, L. C., Damatta, F. M., and Rodrigues, F. (2016). Silicon-induced changes in the antioxidant system reduce soybean resistance to frogeye leaf spot. J. Phytopathol. 164, 768-778. doi: 10.1111/jph. 12497

Thines, B., Katsir, L., Melotto, M., Niu, Y., Mandaokar, A., Liu, G., et al. (2007). JAZ repressor proteins are targets of the SCFCOI1 complex during jasmonate signalling. Nature 448, 661-665. doi: 10.1038/nature05960

Uriarte, R. F., Shew, H. D., and Bowman, D. C. (2004). Effect of soluble silica on brown patch and dollar spot of creeping bentgrass. J. Plant Nutr. 27, 325-339. doi: 10.1081/PLN-120027657

Van, B. J., De Vleesschauwer, D., and Hofte, M. (2013). Towards establishing broadspectrum disease resistance in plants: silicon leads the way. J. Exp. Bot. 64, 1281-1293. doi: 10.1093/jxb/ers329

Van, B. J., Spíchal, L., Novák, O., Strnad, M., Asano, T., Kikuchi, S., et al. (2015a). Silicon induces resistance to the brown spot fungus Cochliobolus miyabeanus by preventing the pathogen from hijacking the rice ethylene pathway. New Phytol. 206, 761-773. doi: 10.1111/nph.13270
Van, B. J., Steppe, K., Bauweraerts, I., Kikuchi, S., Asano, T., and De, V. D. (2015b). Primary metabolism plays a central role in molding silicon-inducible brown spot resistance in rice. Mol. Plant Pathol. 16, 811-824. doi: 10.1111/mpp.12236

Vermeire, M. L., Kablan, L., Dorel, M., Delvaux, B., Risède, J. M., and Legrève, A. (2011). Protective role of silicon in the banana-Cylindrocladium spathiphylli pathosystem. Eur. J. Plant Pathol. 131, 621-630. doi: 10.1007/s10658-0119835-x

Vivancos, J., Labbe, C., Menzies, J. G., and Belanger, R. R. (2015). Silicon-mediated resistance of Arabidopsis against powdery mildew involves mechanisms other than the salicylic acid (SA)-dependent defence pathway. Mol. Plant Pathol. 16, 572-582. doi: 10.1111/mpp. 12213

Waewthongrak, W., Pisuchpen, S., and Leelasuphakul, W. (2015). Effect of Bacillus subtilis and chitosan applications on green mold (Penicillium digitatum Sacc.) decay in citrus fruit. Postharvest Biol. Technol. 99, 44-49. doi: 10.1016/j. postharvbio.2014.07.016

Whan, J. A., Dann, E. K., and Aitken, E. A. (2016). Effects of silicon treatment and inoculation with Fusarium oxysporum $\mathrm{f}$. sp. vasinfectum on cellular defences in root tissues of two cotton cultivars. Ann. Bot. 118, 219-226. doi: 10.1093/aob/ mcw095

Wiese, J., Wiese, H., Schwartz, J., and Schubert, S. (2005). Osmotic stress and silicon act additively in enhancing pathogen resistance in barley against barley powdery mildew. J. Plant Nutr. Soil Sci. 168, 269-274. doi: 10.1002/jpln.2004 20490

Ye, M., Song, Y. Y., Long, J., Wang, R. L., Baerson, S. R., Pan, Z. Q., et al. (2013). Priming of jasmonate-mediated antiherbivore defense responses in rice by silicon. Proc. Natl. Acad. Sci. U.S.A. 110, 3631-3639. doi: 10.1073/pnas. 1305848110

Zellner, W., Frantz, J., and Leisner, S. (2011). Silicon delays Tobacco ringspot virus systemic symptoms in Nicotiana tabacum. J. Plant Physiol. 168, 1866-1869. doi: 10.1016/j.jplph.2011.04.002

Zeyen, R. J., Ahlstrand, G. G., and Carver, T. L. W. (1993). X-ray microanalysis of frozen-hydrated, freeze-dried, and critical point dried leaf specimens: determination of soluble and insoluble chemical elements of Erysiphe graminis epidermal cell papilla sites in barley isolines containing $\mathrm{Ml}-\mathrm{O}$ and $\mathrm{ml}-\mathrm{O}$ alleles. Can. J. Bot. 71, 284-296. doi: 10.1139/b93-029

Zhang, G., Cui, Y., Ding, X., and Dai, Q. (2013). Stimulation of phenolic metabolism by silicon contributes to rice resistance to sheath blight. J. Plant Nutr. Soil Sci. 176, 118-124. doi: 10.1002/jpln.201200008

Zhang, H., Zhang, D., Chen, J., Yang, Y., Huang, Z., Huang, D., et al. (2004). Tomato stress-responsive factor TSRF1 interacts with ethylene responsive element GCC box and regulates pathogen resistance to Ralstonia solanacearum. Plant Mol. Biol. 55, 825-834. doi: 10.1007/s11103-005-2140-3

Zhang, Q., Fry, J., Lowe, K., and Tisserat, N. (2006). Evaluation of calcium silicate for brown patch and dollar spot suppression on turfgrasses. Crop Sci. 46, 1635-1643. doi: 10.2135/cropsci2005.04-0002

Conflict of Interest Statement: The authors declare that the research was conducted in the absence of any commercial or financial relationships that could be construed as a potential conflict of interest.

Copyright (c) 2017 Wang, Gao, Dong, Sun, Shen and Guo. This is an open-access article distributed under the terms of the Creative Commons Attribution License (CC BY). The use, distribution or reproduction in other forums is permitted, provided the original author(s) or licensor are credited and that the original publication in this journal is cited, in accordance with accepted academic practice. No use, distribution or reproduction is permitted which does not comply with these terms. 